\title{
Technology of extraction and primary processing of low-grade and off-balance ores
}

\author{
Anton Cheban ${ }^{1 *}$ \\ ${ }^{1}$ Mining Institute FEB RAS, 51 Turgenev st., Khabarovsk, 680000, Russia
}

\begin{abstract}
In connection with the decline in the quality of reserves of many types of mineral wealth, there is a need to develop mining techniques and technologies that allow for effective development of deposits having increasingly hard mining conditions. In the ores of non-ferrous, rare and noble metals, the concentration of ore minerals in small classes of loosened ore mass is often observed. The paper analyzes the nature of the distribution of gold, tungsten, lead and some other useful components in the original ores, and presents methods for the treatment and primary processing of the ore mass with the separation of enriched classes. An engineering and technological solution has been proposed that provides an increase in production efficiency in opencast mining of deposits, the ores of which, after disintegration, are characterized by the enrichment of small classes, due to the separation of substandard ore siftings in the mine face directly during mining operations, their subsequent sorting and processing, as well as increased productivity and extended functionality of mining equipment. The use of the mining complex when excavating the rock mass will provide a reduction in the cost price, which will allow the complexstructured areas of the deposits to be involved in the development, composed of low-grade and off-balance ores.
\end{abstract}

Keywords: mining, selective excavation, enriched classes, ore screening, mining complex, lump separation, batch sorting.

\section{Introduction}

Currently, in the mining industry there is a tendency of reduced quality of reserves of most types of mineral wealth, because previously explored near-surface conditional reserves are almost completely mined out [1]. At the same time, the demand for metals in the world is steadily increasing, so according to [2], the extraction of metals in the world from 1987 to 2014 increased several times: iron - from 502 to 1,966 million tons, manganese - from 12.5 to 48,9 million tons, copper - from 6,387 to 18,228 thousand tons, lead - from 2,275 to 5,634 thousand tons. With the development of scientific and technological progress in mining and ore dressing, it became possible to develop deposits that were previously considered unprofitable [3-8], which became an important factor in the growth of reserves of almost the entire spectrum of minerals. In this connection, there was a decrease in the requirements for the minimal content of the useful component in ore, as well as for the geological and technological characteristics of extracted materials. So the minimal

\footnotetext{
*Corresponding author: chebanay@mail.ru
} 
industrial content of metal in ore from 1987 to 2014 decreased significantly: for iron - from 40 to $30 \%$; manganese - from 32 to $22 \%$; copper - from 0.7 to $0.4 \%$; lead - from 1.1 to $0.6 \%[2]$.

\section{Distribution of useful components in the original ore}

A feature of non-ferrous, rare and noble metal ores is their concentration in minerals ranging in size from the first micrometers to millimeter values. At the same time, grains of ore minerals in ordinary and poor ores are closely intergrown with brittle vein minerals, therefore, during explosive and mechanical disintegration, the effect of accumulation of valuable components in ore siftings is manifested. Deposits of noble metals are characterized by a wide range of their concentration in small (0.n-n m3) volumes of ore, therefore, for such objects it is advisable to use a combination of highly selective mechanical extraction from the rock ore in natural bedding and large-volume selective extraction after explosive loosening of the rock ore.

Studies on the nature of gold and silver distribution in the lost ore screenings during the underground mining of the Irokinda mine showed that in the $-6 \mathrm{~mm}$ grades the gold content is $7-29 \mathrm{~g} / \mathrm{t}$, silver $-7-44 \mathrm{ppm}$, and in screened ore size $+6 \mathrm{~mm}$ gold is less than $3 \mathrm{~g} / \mathrm{t}$, silver $-5 \mathrm{~g} / \mathrm{t}$ [9]. In this case, the layer of enriched ore siftings, accumulating in the clearing space of the mine in cracks and uneven workings, is removed using vacuum installations.

An increased content of the useful component is characteristic for fine fractions of tungsten ores. The study of a technological sample of a lean ore from one of the tungsten deposits of Primorsk Territory showed that with an average content of the useful component in the original rock ore of $0.24 \%$, the content in the $-100+50 \mathrm{~mm}$ class was $0.18 \%$, in the $-50+20 \mathrm{~mm}$ class $-0.25 \%$, in the $-20+5 \mathrm{~mm}$ class $-0.30 \%$, on average for classes $-100+5 \mathrm{~mm}-0.21 \%$ [1]. In screened ore of $-5 \mathrm{~mm}$, the metal content was $0.45 \%$, which is 2.2 times higher than the average grade for $-100+5 \mathrm{~mm}$. At the underground BomGorkhonsky mine, the average content of tungsten trioxide is $0.65 \%$, and the content of the useful component in the screened ore is on average 1.1\% [10].

Technological samples of the bottom-hole lead-zinc ore of the Uchkulach deposit (Uzbekistan) showed that in the ore delivered from the bottom without reloading, there is a clear tendency to enrichment with lead of fine grades. This allows, directly at the screening stage, to separate the fine class of $-25 \mathrm{~mm}$ and feed it to the concentrate, as it contains 2-3 times more lead than ores of the +25 mm class [11]. Therefore, one of the most important conditions necessary for the effective use of this technology is to minimize the amount of ore reloading after its extraction from the mine face and before sorting.

Concentration of ore minerals and aggregates containing them in fine classes of disintegrated ore mass is often observed, especially for ores characterized by disseminated and finely disseminated sulfide mineralization associated with quartz.

The presence of an increased content of the useful component in screened ore is also typical for some non-metallic minerals. Thus, in the poor apatite-nepheline ores of the Oleniy Ruchei deposit with an average content of the useful component of 5.4\%, in the +20 mm grades, the content of phosphorus pentoxide $\mathrm{P}_{2} \mathrm{O}_{5}$ was $3.66 \%$, in the ore screening -10 $\mathrm{mm}-7.22 \%$ [12]. In the ordinary ore of the deposit with an average grade of the useful component in the technological sample of $10.1 \%$, in the grades of $+20 \mathrm{~mm}$, the content of the useful component was only $5.48 \%$, and in screened ore with a size of $-10 \mathrm{~mm}$, the apatite content was $18.05 \%$. 


\section{Methods for the treatment and primary processing of ore mass with the separation of enriched classes}

At the Tyrnyauz tungsten-molybdenum plant, the following methods have been developed for sorting substandard rock ore. Biotite hornfelses with veined molybdenum mineralization are preliminarily sorted by separating enriched size classes in the process of stage crushing [13]. For biotite hornfelses, the enriched size class is fines less than $13 \mathrm{~mm}$, the yield of the enriched size class is $18-20 \%$, the molybdenum content in it is 2.3 times higher than in the original rock ore. In the method for enhancing the quality of ores [14], it is proposed to separate from the flow of substandard ores, fed along the ore slope with slots, the most enriched fine fractions less than $5 \mathrm{~mm}$ in size, which are then fed for enrichment; fractions of $+5 \mathrm{~mm}$ in size are not processed and are fed to the storage site of temporarily substandard ore.

For the conditions of the Yakovlevsky mine, a method is proposed for controlling the quality of ore during underground mining of powerful, complex-structured deposits of rich iron ores [15]. At the deposit, loose and semi-friable iron-mica-martite ores with a high iron content (more than 65\%) have low strength characteristics and are intensively destroyed when chipping with a mining combine, it is proposed to loosen such ores at a high cutting speed and a low feed rate of the cutting body, as a result of which more than $90 \%$ of the ore is represented by fine fractions up to $10 \mathrm{~mm}$. Ores with an iron content of less than $60 \%$ have higher strength, and it is proposed to break them down with a lower cutting speed and a higher feed for a higher yield of coarse fractions. Gross mining of different grade ore is carried out, followed by its transportation to the screen, where rich fine fractions are separated, which do not require additional enrichment. In the method of open-pit mining of complex-structured deposits of solid minerals [16], it is proposed to develop a rock mass consisting of waste rocks, conditioned and substandard ores, by means of an open-pit mining combine equipped with a classification unit for separating enriched ore screenings in the form of an undersize product, which, by means of a pneumatic conveying system, is directed from the combine to the container of the vehicle. The oversize product is poured along a chute behind the combine into an open trench, and is selectively removed by a loader, after which dump trucks transport the rock mass to its destination (waste rock dump, warehouse of temporarily substandard ore, processing plant).

During the development of complex-structured deposits, in the production block some areas of conditioned and substandard ores, as well as waste rocks, are identified. Currently, automated control systems for the selective mining of ore have been developed, which provide high-precision positioning of the excavator in the mine face, the required trajectory of the bucket relative to the localization zones of various types of rock mass, as well as the ability to identify the quality of the rock mass in the bucket [17]. In some cases, together with substandard ores, a significant amount of the useful component contained in the production block is delivered to the dump. So, in the early 1990s, at the Tyrnyauz tungstenmolybdenum plant, which at that time was operating according to the traditional technology without lump separation and batch sorting of ores, the share of conditioned ores accounted for only $13.5 \%$ of the mined rock mass and $34.6 \%$ of the metal, and $86.5 \%$ of the rock mass went to the dump for substandard ores, catching $65.4 \%$ of the metal contained in the production block [13].

\section{Results}

To increase the productivity of single-bucket excavators, design schemes of mining complexes are proposed that allow converting the cyclic process of scooping up rock mass with a bucket into a continuous process of loading it into a vehicle by means of a conveyor 
[18-19]. A common disadvantage of technological schemes with mining and loading into dump trucks of rock mass with single-bucket excavators and mining complexes is that the substandard ore, together with the fine fraction enriched with a useful component, will be delivered to the warehouse of temporarily substandard ore, and in essence, to the dump.

The paper proposes a technical and technological solution that provides an increase in the efficiency of a mining and processing enterprise during open-cut mining of deposits, the ores of which, after disintegration, are characterized by the enrichment of small classes, due to the separation of small classes of substandard ore in the mine face directly during mining, its subsequent sorting and processing, and also increasing productivity and expanding functionality of mining equipment.

Based on the data of operational exploration and technological testing, a digital model of the mining block is formed, loaded into the on-board automated control system of the mining complex 1, which carries out selective mining of the rock mass prepared for excavation (Fig. 1). Taking into account the position of the contours and zones of localization of technological types of rock mass, the mining complex 1 with working equipment 2 of the hydraulic excavator "front shovel" type is performing extraction (Position I). The bucket 3 is unloaded into a rotary conveyor 4 (Position II), which, by means of blades 5 , moves the rock mass to the unloading window 6 and dumps it onto the dump conveyor 7, with which the dump truck is loaded.

When moving substandard ore by the rotary conveyor 4 , the ore screening is sieved through vibrating screens 8 , collected in the storage 9 and by means of the pneumatic system 10 is moved into the container 11 of the vehicle. In case of excavation of conditioned ore or waste rock, vibrating gratings 8 are blocked from below with dampers, and the entire volume of rock mass is directed to the unloading window 6 . Waste rocks and oversized product of substandard ore are transported by dump trucks, respectively, to the waste rock dump and warehouse of temporarily substandard ore. Conditioned ore is transported to the in-pit crushing and screening plant, where, after crushing by screens, it is divided into size classes with the separation of ore screenings. After that, the grades of conditioned ore are separately fed to the lump separation module, also located in the quarry, with the separation of the pre-enriched product (primary concentrate) and empty inclusions, which will be sent from the open pit to the concentrator and to the waste rock dump, respectively.

Empty inclusions can be separated from ore screenings of conditioned and substandard ore by means of batch sorting, gravity and other methods [20].

The proposed technical and technological solution can be applied in the development of the Skrytoe tungsten deposit in Primorsk Territory, which has significant reserves of tungsten trioxide, represented by ores with a very low metal content, in connection with which, even the issue of transferring these reserves to the category of off-balance ores is put forward [1]. It is also possible to use the proposed solution to involve in the development of poor and off-balance ores of the Vostok-2 and Lermontovskoe deposits, the rich ore areas of which have already been exhausted by now. 

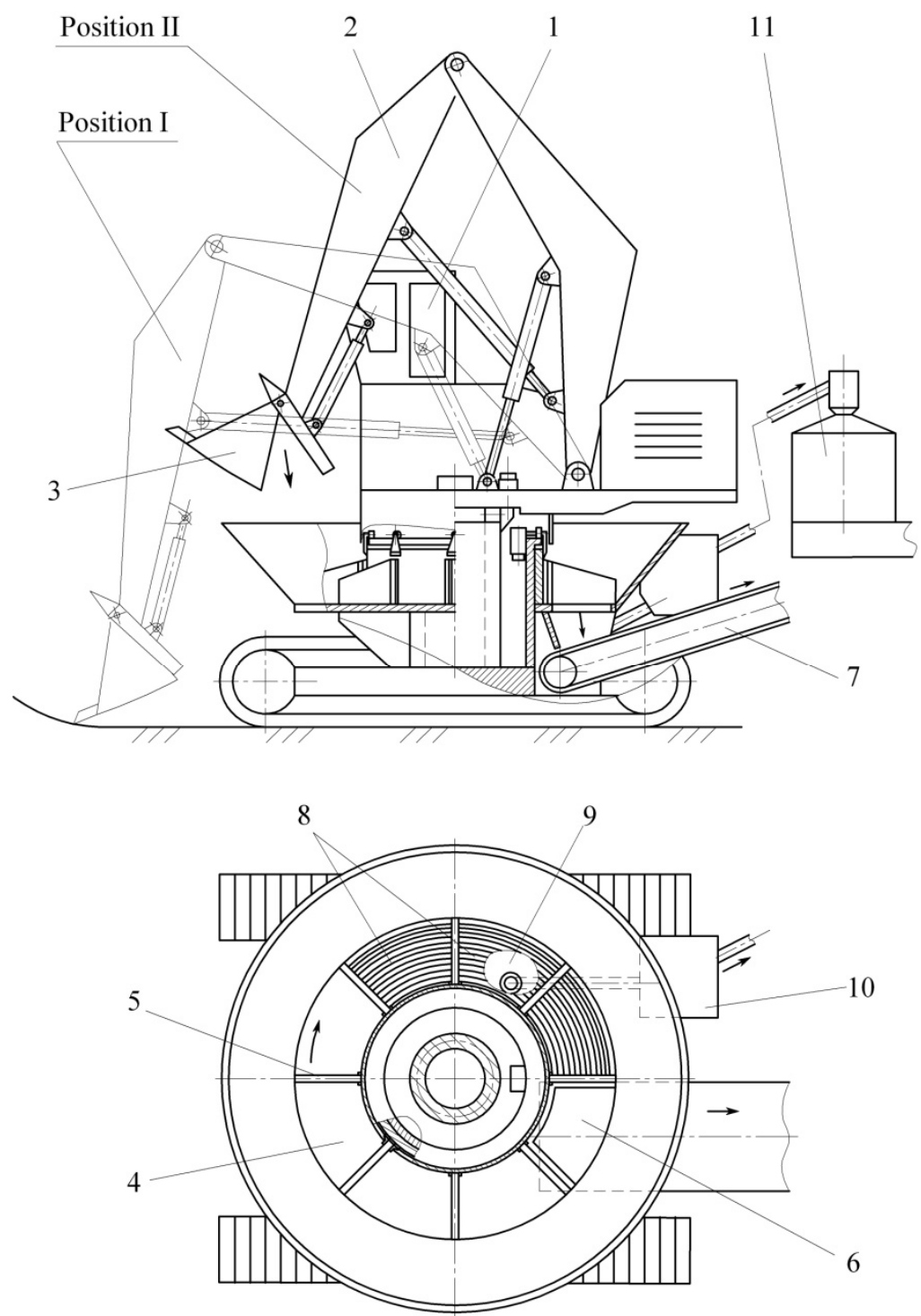

Fig. 1. Schematic diagram of a mining complex that provides separation of enriched ore screenings

\section{Conclusion}

The proposed technical and technological solution with the use of the mining complex will ensure an increase in the recovery factor of mineral raw stock in the development of complex-structured deposits, the ores of which are characterized by natural enrichment of small classes, due to the separation and subsequent processing of ore screenings of substandard ores, which, using traditional mining technologies, would be delivered to the storage site for temporarily substandard ore. The mining complex, based on the data of the digital model of the production block being developed, provides selective extraction of ores of different conditions. The bucket of the mining complex is unloaded into a rotary conveyor, which moves the rock mass to the dump conveyor, with the help of which the dump truck is loaded, thus, the cyclic process of mining the rock mass is converted into a 
continuous process of loading the vehicle. The technology provides the formation of different-quality flows of ore mass for separate processing with lump separation and batch sorting to obtain a pre-enriched product. It is advisable to process the obtained ore screenings using the activation leaching technology, which allows the extraction of valuable components at the level of 73-95\%, or using flotation after preliminary regrinding of the material. An increase in the productivity of mining the rock mass, as well as its intrapit primary processing, will ensure a decrease in the cost of work, enabling to involve in the development some complex structural sections of deposits, composed of poor and offbalance ores.

\section{References}

1. L.A. Samatova, E.D. Shepeta, Mining Information and Analytical bulletin, 4, 187199 (2013)

2. L.V. Oganesyan, Mineral resources of Russia. Economics and Management, 2, 48-52 (2019)

3. M. D. Adams, Gold Ore Processing: Project Development and Operations. 2nd ed. (Amsterdam: Elsevier, 2016)

4. N. N. Hidayah, S. Z. Abidin, Minerals Engineering, 121, 146-157 (2018)

5. L. Sinclair, J. Thompson, Hydrometallurgy, 157, 306-324 (2015)

6. H. Jang, E. Topal, Y. Kawamura, Applied Soft Computing Journal, 32, 1-12 (2015)

7. S. R. Smith, C. Zhou, J. Y. Baron, Y. Choi, J. Lipkowski, Electrochimica Acta, 210, 925-934 (2016)

8. K. A. Natarajan, Biotechnology of Metals: Principles, Recovery Methods and Environmental Concerns (Amsterdam: Elsevier, 2018)

9. A.M. Pavlov, Yu.M. Semenov, Mining Information and Analytical Bulletin, 11, 2429 (2007)

10. R.A. Sitnikov, Bulletin of the Chita State University, 2, 18-22 (2010)

11. K.S. Sanakulov, S.V. Rudnev, A.V. Kantsel, Gornyi Vestnik of Uzbekistan, 1, 17$20(2011)$

12. S.V. Tereshchenko, V.V. Marchevskaya, D.N. Shibaeva, V.N. Aminov, Processing of ores, 3, 32-38 (2018) DOI: 10.17580/or.2018.03.06.

13. V.V. Novikov, E.P. Leman, G.V. Zhagulo, Processing of ores, 3-4, 4-12 (1992)

14. V.A. Shestakov, V.A. Khakulov, G.A. Semochkin, A.S. 1120104 USSR. Method of forming the quality of ores during mining and ore skat for its implementation, applied 14.03.1983 (1984)

15. V. P. Zubov, A. A. Antonov, Patent 2459081 RF. Method of ore quality control during underground mining of powerful complex-structured deposits of rich iron ores, declared 26.01.2011 (2012)

16. A.Yu. Cheban, Patent 2687213 RF. Method of open development of complexstructured deposits of solid minerals, applied 27.04.2018 (2019)

17. V.A. Khakulov, E.I. Krapivsky, B.Kh. Blaev, V.A. Shapovalov, Ore concentration, 5, 33-39 (2018) DOI: 10.17580/or.2018.05.06.

18. A. Yu. Cheban, Mining equipment and electromechanics, 3, 8-11 (2017)

19. V. A. Kazakov, I. P. Kubyshkin, Mining equipment and electromechanics, 12, 35-38 (2007)

20. A. G. Sekisov, A. Yu. Lavrov, D. V. Manzyrev, Bulletin of the Chita State University, 2, 106-111 (2011) 